\title{
MURDER AND THE TORT OF INTENTIONAL INFLICTION OF EMOTIONAL DISTRESS
}

The vast majority of states have recognized the tort of intentional infliction of emotional distress, ${ }^{1}$ also known as the tort of outrage. ${ }^{2}$ There have been only a handful of instances, however, in which actions have been brought seeking recovery for emotional distress stemming froin the murder of a third party. ${ }^{3}$ Courts generally have been willing to grant recovery on this basis only in cases where the plaintiff was both related to the murder victim and present at the scene of the murder. ${ }^{4}$ Furthermore, one court refused to recognize an action for einotional distress stemming from the inurder of a third party on the ground that the state's wrongful death statute "occupied the field" and thus precluded a common law recovery. ${ }^{5}$

This note discusses the extent to which a murderer should be liable to members of the victin's immediate family for emotional distress suffered as a result of the murder. After a brief description of the traditional elements of the tort of intentional infliction of emotional distress, ${ }^{6}$ this note examines the reasons traditionally given for making "presence" a prerequisite for recovery. ${ }^{7}$ The presence requirement is said to serve three purposes: (1) it ensures that the mental impact is anticipated by the defendant; ${ }^{8}$ (2) it guarantees that the emotional distress is genuine and severe; ${ }^{9}$ and (3) it provides a shield against unlimited and unduly burden-

1. See infra note 14 and accompanying text.

2. See Dyar v. Florida Farm Bureau Mut. Ins. Co., 496 F. Supp. 695, 696 (N.D. Fla. 1980); Star v. Rabello, 97 Nev. 124, 125, 625 P.2d 90, 91 (1981); Lund v. Caple, 100 Wash. 2d 739, 742, 675 P.2d 226, 228 (1984).

3. See Garland v. Herrin, 724 F.2d 16 (2d Cir. 1983); Knierim v. Izzo, 22 Ill. 2d 73, 174 N.E.2d 157 (1961); Markowitz v. Fein, 30 A.D.2d 515, 290 N.Y.S.2d 128 (1968); Koontz v. Keller, 52 Ohio App. 265, 3 N.E.2d 694 (1936).

4. See, e.g., Ledger v. Tippitt, 164 Cal. App. 3d 625, 642, 210 Cal. Rptr. 814, 824 (1985) ("recovery is allowed when a relative is killed or threatened with death in plaintiff's presence"); Maney v. Maloney, 101 A.D.2d 403, 477 N.Y.S.2d 436 (1984) (remanded to determine whether plaintiff was present when brother was shot to death); see also RESTATEMENT (SECOND) OF TORTS $\S 46(2)$ (a) (1965) (actor subject to liability if he causes severe emotional distress to a family member "who is present at the time" he engages in the outrageous conduct).

5. See Garland v. Herrin, 724 F.2d 16, 20 (2d Cir. 1983) (interpreting New York law and holding that actions arising from death of an individual must have statutory basis); see infra notes 84-98 and accompanying text.

6. See infra notes 11-18 and accompanying text.

7. See infra notes $19-83$ and accompanying text.

8. See infra notes 26-50 and accompanying text.

9. See infra notes 51-57 and accompanying text. 
some liability. ${ }^{10}$ This note argues that the first two reasons, although supportable in cases involving nonfatal third party injuries, are insupportable in cases involving the murder of an immediate family member. The note also argues that the third reason is unsound with respect to cases involving intentionally caused death. The note concludes that because intentional infliction of emotional distress is a direct and not a derivative injury, wrongful death statutes should pose no bar to recovery.

\section{The TORT OF INTENTIONAL INFLiction OF EMOTIONAL DisTRESS}

Section 46 of the Second Restatement of Torts defines the scope of the tort of intentional infliction of emotional distress. ${ }^{11}$ Under section 46(1), liability attaches only if the actor, "by extreme and outrageous conduct intentionally or recklessly causes severe emotional distress to another."12 Section 46(2)(a) extends the cause of action to parties not directly subjected to the outrageous conduct: "Where such conduct is directed at a third person, the actor is subject to hability if he intentionally or recklessly causes severe emotional distress[] to a member of such person's immediate family who is present at the time, whether or not such distress results in bodily harm ...."13 Courts in most jurisdictions have expressly adopted section 46(1) of the Restatement, ${ }^{14}$ and the majority of courts that have addressed the issue of emotional distress stemming from third party injuries have followed section $46(2) .^{15}$

10. See infra notes 58-83 and accompanying text.

11. RESTATEMENT (SECOND) OF TORTS $§ 46$ (1965).

12. Id. $\S 46(1)$.

13. Id. $\S 46(2)(\mathrm{a})$.

14. See, e.g., Northrup v. Farmland Indus. Inc., 372 N.W.2d 193, 197 (Iowa 1985) (en banc); Neufeldt v. L.R. Foy Constr. Co., 236 Kan. 664, 667-69, 693 P.2d 1194, 1196-98 (1985); Agis v. Howard Johnson Co., 371 Mass. 140, 145, 355 N.E.2d 315, 317 (1976); Hubbard v. United Press Int'l, Inc., 330 N.W.2d 428, 438-39 (Minn. 1983); Freihofer v. Hearst Corp., 65 N.Y.2d 135, 143, 480 N.E.2d 349, 355, 490 N.Y.S.2d 735, 741 (1985); Grimsby v. Samson, 85 Wash. 2d 52, 60, 530 P.2d 291, 295 (1975) (en banc).

15. Healy v. Counts, 536 F. Supp. 600, 602-03 (D. Colo. 1982) (interpreting Colorado law and denying recovery because plaintiffs were not present at scene); Dyar v. Florida Farm Bureau Mut. Ins. Co., 496 F. Supp. 695, 697 (N.D. Fla. 1980) (no cause of action stated where plaintiff did not witness the alleged bribe); Collier v. Wagner Castings Co., 70 Ill. App. 3d 233, 242, 388 N.E.2d 265, 272 (1979) (no cause of action stated where plaintiffs did not witness the alleged outrageous conduct), aff'd on other grounds, 81 Ill. 2d 229, 408 N.E.2d 198 (1980); Wiehe v. Kukal, 225 Kan. 478, 481-84, 592 P.2d 860, 863-65 (1979) (applying section 46(2)); Star v. Rabello, 97 Nev. 124, 126-27, 625 P.2d 90, 92 (1981) (implicitly adopting section 46(2)); Calliari v. Sugar, 180 N.J. Super. 423, 428-29, 435 A.2d 139, 141-42 (N.J. Super. Ct. Ch. Div. 1980) (explicitly adopting section 46(2)); Maney v. Maloney, 101 A.D.2d 403, 406, 477 N.Y.S.2d 436, 438 (1984) (applying section 46(2) and remanding for determination whether plaintiff was present when brother was shot to death); Rockhill v. Pollard, 259 Or. 54, 64, 485 P.2d 28, 33 (1971) (en banc) (cause of action stated where physi- 
Under section 46 , it is essential that the conduct be outrageous. The commentary to the Restatement states:

Liability has been found only where the conduct has been so outrageous in character, and so extreme in degree, as to go beyond all possible bounds of decency, and to be regarded as atrocious, and utterly intolerable in a civilized community. Generally, the case is one in which the recitation of the facts to an average member of the community would arouse his resentment against the actor, and lead him to exclaim, "Outrageous!"16

The requirement of outrageousness ensures that the emotional distress is genuine and severe. ${ }^{17}$ The need to so ensure the genuineness and severity of the distress arises from the nature of the alleged injury. As one court noted, "[i]t is easy to assert a claim of mental anguish and very hard to disprove it." 18

cian grossly mistreated plaintiff's child in plaintiff's presence); Grimsby v. Samson, 85 Wash. 2d 52, 60, 530 P.2d 291, 296 (1975) (en banc) (explicitly adopting section 46(2)(a)).

16. RESTATEMENT (SECOND) OF TORTS $\$ 46$ comment d (1965).

17. See, e.g., Molien v. Kaiser Found. Hosp., 27 Cal. 3d 916, 927, 616 P.2d 813, 819, 167 Cal. Rptr. 831, 837 (1980) (en banc); Agis v. Howard Johnson Co., 371 Mass. 140, 144, 355 N.E.2d 315, 318 (1976); Samms v. Eccles, 11 Utah 2d 289, 293, 358 P.2d 344, 347 (1961); see also RESTATEMENT (SECOND) OF TORTS $\S 46$ comment $\mathrm{j}$ (1965).

The outrageousness of the defendant's conduct is also probative of whether the plaintiff has in fact suffered an injury. See Hume v. Bayer, 178 N.J. Super. 310, 319, 428 A.2d 966, 970 (N.J. Super. Ct. Law Div. 1981) ("Extreme and outrageous conduct by its nature produces distress in 'normally constituted' persons against whom it is directed.").

18. Gardner v. Cumberland Tel. Co., 207 Ky. 249, 254, 268 S.W. 1108, 1110 (1925).

Courts initially were reluctant to provide redress for mental suffering because they feared a proliferation of claims and thought that it would be too difficult to value mental distress in monetary terms. See W. Keeton, D. Dobbs, R. Keeton \& D. OWen, Prosser And Keeton ON TorTs 55-56 (5th ed. 1984) [hereinafter Prosser \& KeEton]; Restatement (SECOND) OF ToRTS $§ 46$ comment b (1965); see also Molien v. Kaiser Found. Hosp., 27 Cal. 3d 916, 925-30, 616 P.2d 813, 817-21, 167 Cal. Rptr. 831, 835-39 (1980) (discussing historical reluctance to recognize independent action for emotional distress); State Rubbish Collectors Ass'n v. Siliznoff, 38 Cal. 2d 330, 336-38, 240 P.2d 282, 285-86 (1952) (recognizing interest in freedom from emotional distress and rejecting rule that plaintiff must be threatened with immediate physical harm in order to recover for emotional distress); Agis v. Howard Johnson Co., 371 Mass. 140, 143-46, 355 N.E.2d 315, 317-18 (1976) (discussing development of tort of outrage). See generally Magruder, Mental and Emotional Disturbance in the Law of Torts, 49 HARv. L. REv. 1033 (1936). Courts eventually recognized that emo. tional trauma is no more difficult to value than physical pain. See, e.g., Berman v. Allen, 80 N.J. 421, 433, 404 A.2d 8, 15 (1979) ("[C]ourts have come to recognize that mental and emotional distress is just as 'real' as physical pain, and that its valuation is no more difficult."); see also ProsSER \& KEETON, supra at 55 . Courts also came to realize that the floodgates argument was weak because plaintiffs had long been allowed to bootstrap claims for mental distress by appending them to claims for minor physical injuries. See Molien, 27 Cal. 3d at 928, 616 P.2d at 820, 167 Cal. Rptr. at 838 ("If physical injury, however slight, provides the ticket for admission to the courthouse, it is difficult for advoeates of the "floodgates' premonition to deny that the doors are already wide open."); see also Prosser \& KeEton, supra at 55.

Courts have sought to avoid the floodgates problem by requiring that emotional distress be severe in order to be actionable. See Restatement (SECOND) OF TORTS $§ 46$ comment j (1965) ("The law intervenes only where the distress inflicted is so severe that no reasonable man could be 


\section{Limitations ON Liability}

\section{A. The Requirement of "Presence."}

Under section 46(2)(a), the plaimtiff must be "present at the time" the defendant engages in the outrageous conduct. ${ }^{19}$ This requirement apparently apphies regardless of the degree of outrageousness of the conduct. Thus, presence is required whether the outrageous conduct is a physical assault, a threat to kill, or a murder. ${ }^{20}$

Section 46 does contain the following caveat, however: "The Institute expresses no opinion as to whether there may not be other circumstances under which the actor may be subject to liability for the intentional or reckless infliction of emotional distress."21 The commentary accompanying this section notes that the caveat is intended to leave open the possibility that presence may not be required under section 46(2)(a). ${ }^{22}$ An examination of the three traditional reasons for requiring presence-to ensure that the mental impact is anticipated by the defendant, ${ }^{23}$ to guarantee that the emotional distress is genuine and severe, ${ }^{24}$ and to provide a shield against unlimited and unduly burdensome liability 25 -compels the conclusion that presence should not be required in cases involving the murder of a member of the plaintiff's inmediate family.

1. Ensuring that the Defendant Anticipates the Mental Impact. In early cases involving outrageous conduct directed at third parties, courts required the presence of the plaintiff as well as the defendant's awareness of such presence. ${ }^{26}$ It was thought that otherwise the defendant could not be said to have "reasonably anticipated" the harm to the plaintiff. ${ }^{27}$ Courts also required a physical injury stemming from the distress-emo-

expected to endure it."). Courts have concluded, though, that the possibility of a proliferation of claims does not itself justify denying a cause of action. See, e.g., Tobin v. Grossman, 24 N.Y.2d 609, 615,249 N.E.2d 419, 422, 301 N.Y.S.2d 554, 558 (1969) ("[I]f a cognizable wrong has been committed[,1 ... there must be a remedy, whatever the burden of the courts.").

19. RESTATEMENT (SECOND) OF TORTS $\$ 46(2)$ (a) (1965).

20. But see Delia S. v. Torres, 134 Cal. App. 3d 471, 483-84, 184 Cal. Rptr. 787, 795 (1982) (cause of action stated though plaintiff did not witness wife's rape).

21. RESTATEMENT (SECOND) OF TORTS $\$ 46$ caveat (1965).

22. Id. $\S 46$ comment $\mathrm{c}$.

23. See infra notes $26-50$ and accompanying text.

24. See infra notes $51-57$ and accompanying text.

25. See infra notes $58-83$ and accompanying text.

26. PROSSER \& KEETON, supra note 18 , at 65 .

27. See, e.g., Reed v. Ford, 129 Ky. 471, 112 S.W. 600 (1908). In Reed, the plaintiff overheard the defendant threatening to kill the occupant of an adjoining room. Id. at 472-73, $112 \mathrm{~S}$.W. at 601 . The defendant was not aware of the plaintiff's presence. Id. The court denied recovery, holding that the defendant could not have "foreseen or reasonably anticipated" the plaintiff's injuries. Id. at 476, 112 S.W. at 601. 
tional distress could not by itself form the basis of an action. ${ }^{28}$ Furthermore, only certain types of mental disturbances, namely shock and fright, were thought to produce physical injury. ${ }^{29}$ Today, however, liability extends to all forms of emotional distress, even where the distress produced no physical injury. ${ }^{30}$

In many situations involving nonfatal injuries, it might indeed be uureasonable for an actor to expect the outrageous conduct to have an emotional impact on third parties who are not present. For example, suppose $A$ quarrels with $B$ 's husband, $C$, and places a gun to $C$ 's temple, threatening to kill him. If $B$ were present at the scene of the incident, she might suffer severe fright. However, if $B$ were not present, but learned after the fact that a threat had been made and not carried out, her reaction might well be one of relief. The same result would probably occur in many cases involving nonlethal batteries. This is not to say that a person who discovers that his spouse has been threatened or beaten will never suffer severe emotional distress, but only that emotional distress seems unlikely in many situations where the plaintiff is not present to observe the conduct. ${ }^{31}$ Thus in cases involving nonfatal injuries, the presence

\footnotetext{
Although the term "reasonably anticipate" might suggest a negligence standard, the facts of those eases in which recovery was granted indicate that the standard employed was at least onc of recklessness. Prosser \& KEETON, supra note 18, at 65 . Courts no longer inquire whether the emotional injury was reasonably anticipated; the inquiry today is whether the defendant intentionally or recklessly inflicted the injury. See infra notes 33-50 and accompanying text.

28. See, e.g., St. Louis, I.M. \& S. Ry. v. Taylor, 84 Ark. 42, 46, 104 S.W. 551, 553 (1907).

29. One court expressed the rationale for this rule as follows:

It must be conceded that a nervous shock or paroxysm, or a disturbance of the nervous system, is distinct from mental anguish, and falls within the physiological, rather than the psychological, branch of the human organism. ... [Shock or fright affecting the nervous system is] an injury to the body rather than to the mind, even though the mind be at the same time injuriously affected.
}

Sloane v. Southern Cal. R.R., 111 Cal. 668, 680, 44 P. 320, 322 (1896). See also Watson v. Dilts, 116 Iowa $249,252,89$ N.W. 1068, 1069 (1902) ("[F]right may . . . affect the nervous system, which is a distinctive part of the physical system .....").

30. See RESTATEMENT (SECOND) OF TORTS § 46(2)(a) (1965); see, e.g., Savage v. Boies, 77 Ariz. 355, 358, 272 P.2d 349, 351 (1954); Agis v. Howard Johnson Co., 371 Mass. 140, 144, 355 N.E.2d 315, 318 (1976); Hume v. Bayer, 178 N.J. Super. 310, 319, 428 A.2d 966, 970 (N.J. Super. Ct. Law Div. 1981).

31. Where a tort victim suffers permanent bodily harm, the emotional distress to his family may be severe. Thus, it may seem inconsistent to argue that recovery should be denied in such a case yet granted where the tort victim suffers fatal injuries. However, assuming that it is desirable to have the boundaries of tort liability clearly defined, such differential treatment may be warranted. It is much easier to distinguish murder from nonlethal conduct than it is to make distinctions between cases involving nonlethal conduct.

Furthermore, a person injured by nonlethal conduct will have a cause of action against the tortfeasor for battery. On the other hand, if the person dies and is a minor or has no dependents, the murderer will probably be immune from civil suit. See Prosser \& KEETON, supra note 18, at 949 (standard recovery limited to pecuniary loss under most wrongful death statutes). To the extcnt civil redress for intentional torts is punitive, see id. at 9-12 (punitive damages appropriate where defendant acted with "malice" or "evil" motive), justice is served when the surviving victim recovers dam. 
requirement is sound because it is rationally related to the probability and severity of emotional suffering caused by the outrageous conduct.

In contrast, the murder of a close relative imflicts grief regardless of the plaintiff's presence or absence at the scene of the murder. ${ }^{32}$ Thus, where the outrageous conduct is murder, the plamtiff's presence should not be critical because there is little correlation between presence and the probability of injury.

a. Intent. An actor intends that a set of consequences occur not only when he acts with the purpose of bringing about those consequences but also when he believes or knows that those consequences are substantially certain to result from his conduct. ${ }^{33}$ Although the actor must be aware that a particular result is substantially certain, a finder of fact may infer from circumstantial evidence that the actor's state of mind was the saine as that of a reasonable person under the same circumstances. ${ }^{34} \mathrm{It}$ is probable that in many cases the killer is aware that the murder will cause members of the victim's immediate family-even members not present at the scene of the murder-to suffer severe emotional distress. ${ }^{35}$

ages. There is at least as strong an argument for a punitive civil remedy when the victim dies. Yet because most jurisdictions adhere to the presence requirement, defendants often fare better when they kill their victims than when they allow them to live. Cf. N.Y. EST. PowERs \& TRuSTS $\S 11-$ 3.2(b) commentary (McKinney Supp. 1986) (amending prior law to allow action for punitive damages to survive victim so that tortfeasor does not fare better by killing victim).

32. See Leibson, Recovery of Damages for Emotional Distress Caused by Physical Injury to Another, 15 J. FAM. L. 163, 196-99 (1976-1977) (relationship of plaintiff and victim is the only medically sound criteria for predicting whether plaintiff will suffer severe distress upon death of victim; presence at the scene of injury has no bearing on the medical consequences); $c f$. Magruder, supra note 18, at 1044 ("[T]here seems little to choose between the ease where the plaintiff sees a murderous attack upon her aged father, and a case where, after the attack, the daughter comes home and stumbles upon his bloody remains.").

33. Prosser \& KeEton, supra note 18 , at 34.

34. Id. at 36. The Restatement provides an illustration based on the facts of Blakely v. Shortal's Estate, 236 Iowa 787, 20 N.W.2d 28 (1945). RESTATEMENT (SECOND) of TORTS § 46, illustration 15 (1965). In Blakely, a neighbor committed suicide in the plaintiff's kitchen. According to the Restatement, if the deceased was aware that this conduct was substantially certain to result in extreme distress to the plaintiff, he acted intentionally and therefore is liable. Id. This illustration is inconsistent with section $46(2)$ because the plaintiff in Blakely did not witness the suicide.

In Blakely, the defendant's conduct was self-directed rather than directed at another. It makes little sense to allow recovery when the defendant kills himself but to deny it when he kills another. Compare Garland v. Herrin, 554 F. Supp. 308 (S.D.N.Y.), rev'd, 724 F.2d 16 (2d Cir. 1983). In Garland, the plaintiff discovered her daughter's "hideously battered body and the blood and brainmatter, which had been spattered about the room." Id. at 311-12. The court of appeals held that the plaintiff's claim for emotional distress was not actionable. Garland v. Herrin, 724 F.2d 16, 21 (2d Cir. 1983).

35. See Magruder, supra note 18 , at $1044-45$ ("When a murderer kills his victim, he knows that an acute shock will inevitably be caused to the near relatives, though of course he is not acting for that purpose."). 
To date, however, only one court has recognized that the act of committing murder may reflect an intent to inflict emotional distress upon members of the victim's immediate family. In Knierim v. Izzo, ${ }^{36}$ the defendant told the plaintiff that he intended to kill her husband. $\mathrm{He}$ then carried out his threat. ${ }^{37}$ Nothing in the facts of the case indicates that the murder was committed with the purpose of causing distress to the plaintiff. The court held that the allegations made by the plaintiff stated a cause of action. ${ }^{38}$

The holding in Knierim illustrates an anomaly in this area of tort law. Had the defendant not carried out his threat, the plaintiff would have had a cause of action for intentional infliction of emotional distress. ${ }^{39}$ However, had the defendant killed the plaintiff's husband without first telling the plaintiff of his intent to do so, the plaintiff would have no cause of action unless she had actually witnessed the murder. ${ }^{40}$ This anomaly is especially striking because the probability that severe distress will be experienced is obviously higher in the latter situation.

In cases in which the defendant does not know that the victim is married, it might be argued that the defendant could not possibly have been "substantially certain" that the murder would cause the victim's spouse to suffer severe emotional distress. The presence of the plaintiff arguably ensures that the defendant is aware of the existence of others who may be affected emotionally by his conduct. ${ }^{41}$ Yet this conclusion is unsound for two reasons. First, the presence requirement is overinclusive because many killers know that the victim has a family. Second, even if the defendant does not know that the victim has a family, his conduct is still reckless in this regard. ${ }^{42}$

36. 22 Ill. 2 d 73, 174 N.E.2d 157 (1961).

37. Id. at 83,174 N.E.2d at 163 .

38. Id. at 87,174 N.E.2d at 165 .

39. See, e.g., Rogers v. Williard, 144 Ark. 587, 223 S.W. 15 (1920) (defendant threatened to shoot plaintiff's husband; recovery for physical and emotional suffering granted).

40. See RESTATEMENT (SECOND) OF TORTS $§ 46$ (1965); supra note 4 and accompanying text.

41. Cf. Reed v. Ford, 129 Ky. 471, 476, 112 S.W. 600, 601-02 (1908) (denying recovery because defendant was unaware that plaintiff was present in adjoining room listening to defendant's violent threats).

42. There is yet another reason why the requirement of presence is unsound: it is inconsistent with the doctrine of "transferred intent." Although the transferred intent doctrine has traditionally been applied only in actions arising under the old writ of trespass, in principle it should be equally applicable in cases involving intentional infliction of emotional distress. See Prosser \& KeEToN, supra note 18, at 65 ("There seems to be little reason to apply [the transferred intent doctrine] when the plaintiff suffers physical harm, and to reject it where there is mental damage."); Note, Application of Transferred Intent to Cases of Intentional Infiction of Emotional Distress, 15 PAC. L.J. 147, 161-70 (1983) (arguing that transferred intent doctrine should be applied in cases involving intentional infiction of emotional distress).

The transferred intent doctrine can be illustrated by a simple example. $A$ shoots at $B$ with intent to harm $B$ but hits $C$ instead. $A$ has committed a battery upon $C$; his intent to harm $B$ was 
b. Recklessness. Many cases of intentional infliction of emotional distress involve conduct that is reckless rather than intentional. ${ }^{43}$ Reckless conduct differs from intentional conduct in two respects: (1) there need only be a strong probability, as opposed to a substantial certainty, that the particular harm will follow from the conduct; and (2) the actor need not be aware of this strong probability. ${ }^{44}$ Although it may not always be substantially certain that the members of a murder victim's family will experience emotional distress, im most instances there is undeniably a strong probability that they will. ${ }^{45}$ That the defendant does not know that the victim has a family should be irrelevant under a recklessness standard because there is a high probability that any given victim will be survived by immediate family members.

Several recent cases have recognized that surviving family members may have a cause of action for emotional distress caused by an actor's reckless failure to act. ${ }^{46}$ For example, in Barnes v. Double Seal Glass Co., 47 the plaintiffs' son was accidentally injured at his place of employment. The plaintiffs alleged that the employer failed to secure proper

"transferred" to $C$. The justification for the transferred intent doctrine derives from the wrongfulness of the defendant's conduct. Prosser \& KeETON, supra note 18, at 38 ("Having departed from the social standard of conduct, the defendant is liable for the harm which follows from the act, although this harm was not intended.").

With rare exceptions, see, e.g., Lambert v. Brewster, 97 W. Va. 124, 127, 125 S.E. 244, 245 (1924) (applying the transferred intent doctrine in case involving emotional distress), the transferred intent doctrine has been applied only in cases that involve two of the three torts derived from the old writ of trespass-battery, assault and false imprisonment. Prosser \& Keeton, supra note 18, at 38. Thus, if $X$ shoots $A$ and misses $B$, he can be held liable for assaulting $B$ even though he only intended a battery upon $A$. Restatement (SECOND) OF TORTs $\S 32$ comment b (1965). But if $X$ shoots $A$ and as a result causes extreme emotional distress to $B, B$ cannot invoke the transferred intent doctrine. The only difference between these two situations lies in the nature of the mental injury inflicted. 1t is unpersuasive to argue that different treatment is justified on that basis alone. The limitations on the transferred intent doctrine do not rest upon sound reasoning but rather upon outdated precedent. See Prosser \& KEETON, supra note 18, at 65 ("[P]robably for the simple reason that emotional distress did not fall within the framework of the old action of trespass where 'transferred intent' arose, rarely does a case so much as mention it by analogy.") (footnote omitted).

43. See, e.g., Womack v. Eldridge, 215 Va. 338, 210 S.E.2d 145 (1974) (defendant deceitfully obtained photograph of plaintiff for use in connection with child molesting case; although defendant's purpose was not to inflict emotional distress, “[a] reasonable person . . . should have recognized the likelihood of the serious mental distress that would be caused in involving an innocent person in child molesting cases"); see also RESTATEMENT (SECOND) of TORTS $\S 46$ comment a (1965).

44. Restatement (SECOND) OF TORTS $\S 500$ comment $f(1965)$.

45. See Garland v. Herrin, 724 F.2d 16, 18 (2d Cir. 1983) (defendant conceded that he recklessly inflicted emotional distress when he murdered the plaintiffs' daughter).

46. De Cicco v. Trinidad Area Health Ass'n, 40 Colo. App. 63, 573 P.2d 559 (1977) (refusal to provide ambulance service to critically ill woman); Barnes v. Double Seal Glass Co., 129 Mich. App. 66,341 N.W.2d 812 (1983) (failure to give prompt medical care to employee after work-related accident); Grimsby v. Samson, 85 Wash. 2d 52, 530 P.2d 291 (1975) (en banc) (failure of physician to give patient medical attention necessary to save her life).

47. 129 Mich. App. 66, 341 N.W.2d 812 (1983). 
medical treatment for the boy and permitted him to die in order to avoid workmen's compensation hability. ${ }^{48}$ The court held the plaintiffs stated a cause of action under the tort of outrage. ${ }^{49}$

Thus, ironically, surviving family nembers seeking recovery for emotional distress have fared better where the death resulted froin a reckless failure to act. The presence requirenent creates this anomaly. Passive conduct cannot be witnessed; consequently, actions arising fron passive conduct, unlike actions arising from affirmative conduct, will not fail for lack of presence. ${ }^{50}$

2. Guaranteeing that the Emotional Distress is Genuine. The commientary to section $46(2)$ of the Restatement indicates that one reason for the presence requirement is that "the distress of a woman who is informed of her husband's murder ten years afterwards may lack the guaranty of genuineness which her presence on the spot would afford."51 Even assuming that the guaranty of genuineness would be absent in such a case, ${ }^{52}$ the situation described is extremely unusual. Most persons will learn of the murder of a spouse within hours and will suffer genuine distress as a result. Thus, the guaranty-of-genuineness justification for the presence requirement is weak. Limits on liability should be guided by the general rule, not the rare exception..$^{53}$

Again, a distinction can be made between cases involving murder and cases involving the infliction of nonfatal injuries. In cases involving nonfatal injuries, it may well be true that only individuals who are present at the scene of the incident are likely to suffer severe and genuine distress. But in cases imvolving fatal injuries, particularly where the death is a violent one, surviving fainily meinbers will suffer severe emo-

48. Id. at 70,341 N.W.2d at 814 .

49. Id. at 77,341 N.W. $2 \mathrm{~d}$ at 818 .

50. In one case involving passive conduct, the court did attempt to reconcile its decision to grant recovery with the presence requirement. In Grimsby v. Samson, 85 Wash. 2d 52, 530 P.2d 291 (1975) (en banc), the plaintiff alleged that his wife died because a physician recklessly failed to givc her medical attention. Id. at 53,530 P.2d at 292. The court held the presence requirement was satisfied because the plaintiff alleged that he watched his wife "die right in front of his eyes." Id. at 60,530 P.2d at 295 (emphasis in original). The court's attempted reconciliation is unpersuasive. The plaintiff in Grimsby witnessed only the consequences of the defendant's wrongdoing. Had the case involved a murder, and had the plaintiff only witnessed the consequences of the wrongful act and not the wrongful act itself, recovery for emotional distress would be denied under section 46(2) of the Restatement.

51. REstatement (SECOND) OF TORTS $\S 46$ comment $l$ (1965).

52. Lack of knowledge may in fact intensify the suffering, as in cases involving soldiers missing in action.

53. See Holmes, The Path of the Law, 10 HARv. L. Rev. 457, 462 (1897) ("I hardly think it advisable to shape general theory from the exception...."). 
tional distress even if they are not present at the scene. ${ }^{54}$ In such cases, presence is not necessary to ensure the genuineness of the distress.

Furthermore, requiring presence at the scene of the murder to ensure that the distress suffered is genuine is inconsistent with other apphcations of the tort of outrage. For example, merely hearing a fabricated tale concerming the death or severe injury of a family meinber may give rise to actionable enotional distress..$^{55}$ The guaranty of genuineness in such a case, however, is weak coinpared to the guaranty inherently present in the case of an actual inurder: in the former case, the grief will be temporary; in the latter case, the grief will probably last a lifetime..$^{56}$ It is indeed anomalous that $A$ is hable under the tort of outrage if he falsely informs $B$ that his child is dead, but not hable if he actually murders $B$ 's child. 57

3. Limiting Liability. A final justification advanced for the presence requirement is that it provides a means by which liability can be limited. ${ }^{58}$ Solne contend that such a boundary is needed because there are no other ineans to limit hability and because pubhic pohicy militates against unhimited and unduly burdensome tort hability. ${ }^{59}$ The public policy concerns are voiced in cases involving neghigent infliction of emo-

54. See supra note 32 and accompanying text.

55. E.g., Savage v. Boies, 77 Ariz. 355, 272 P.2d 349 (1954) (police officer tricked woman suspected to be insane into entering hospital by fabricating story that her child was seriously injured); Bielitski v. Obadiah, 61 D.L.R. 494 (1921) (defendant spread false rumor likely to reach plaintiff that plaintiff's son hanged himself).

In other cases, plaintiffs have recovered for emotional distress stemming from the intentional mishandling of corpses. See Prosser \& KeETon, supra note 18, at 63; see, e.g., Herbertson v. Russell, 150 Colo. 110, 126, 371 P.2d 422, 430 (1962) (Frantz, J., specially concurring) (noting that it is "most anomalous" that a "parent may not be recompensed for the mental anguish resulting from the injury or death of his or her child, but may be recompensed for such anguish where the clay to which it has been reduced in death has been disturbed").

56. The Restatement notes that the "intensity and the duration of the distress are factors to be considered in determining its severity." RESTATEMENT (SECOND) OF TORTS $\S 46$ comment $j$ (1965) (emphasis added). Consider the following statement by a spokesperson for a victims' group called Parents of Murdered Children of New York State: "I buried my daughter, but I cannot bury my anger and my pain. Time and again we see short-term sentences given to the criminals while we, the victims, serve lifetime sentences of fear, grief and violation." N.Y. Times, April 21, 1981, at D1, col. 1; see also Young, Victims of Crime: The Great American Scandal, 23 JUDGES J. 8, 9 (1984) ("[T] he families and friends who live on know that murder does not produce one victim who 'blessedly' rests in peace-it leaves behind many life-time sorrows.").

57. Cf. Prosser \& KeEton, supra note 18, at 65 ("It is a strange distinction which ... finds a cause of action in mental disturbance at the mistreatment of househoid furniture, and none in shock at the sight of the mutilated body of a murdered sister.").

58. RESTATEMENT (SECOND) OF TORTS $§ 46$ comment $I$ (1965).

59. See, e.g., id.; Prosser \& KeEton, supra note 18, at 65. 
tional distress ${ }^{60}$ as well as in cases involving the tort of outrage. ${ }^{61}$ Because of the distinction between conduct that intentionally causes death and conduct that negligently causes death, however, public policy concerns should be weighed differently in each context.

In the field of negligent infliction of emotional distress, courts have struggled to adopt rational standards for limiting liability. The difficulty arises in drawing distinctions between classes of potential plaintiffs. For example, if a mother is allowed to recover for the negligently caused death of her child, can a court logically deny recovery to other close relatives or friends of the child who also have been affected by his death?

Confronted with this dilemma, a majority of jurisdictions have adopted the "zone of danger" limitation. ${ }^{62}$ Under this approach, a plaintiff may recover only if he is personally threatened with physical harm by the defendant's negligence and only if he suffers physical injury from the shock or fright of seemg a loved one placed in peril. ${ }^{63}$ Some authorities have found the zone-of-danger rule to be consistent with traditional notions of duty of care. ${ }^{64}$ Courts have recognized, though, that the rule places an arbitrary limitation on liability. ${ }^{65}$ Yet the rule retains its vitality because "arbitrary distinctions are an inevitable result of the drawing of limes which circumscribe legal duties," 66 and because it is believed that public policy dictates that limitations be placed on tort liability. ${ }^{67}$

60. See Sinn v. Burd, 486 Pa. 146, 163, 404 A.2d 672, 681 (1979) (public policy concerns are at "the heart of the controversy"); PROSSER \& KEETON, supra note 18, at 366; see also infra notes 62 78 and accompanying text.

61. See, e.g., Koontz v. Keller, 52 Ohio App. 265, 270, 3 N.E.2d 694, 697 (1936).

62. See Bovsun v. Sanperi, 61 N.Y.2d 219, 228-29, 461 N.E.2d 843, 847, 473 N.Y.S.2d 357, 361 (1984) (noting that a majority of courts have adopted zone-of-danger rule); Note, Negligent Infliction of Emotional Distress: Keeping Dillon in Bounds, 37 WASH. \& LEE L. REV. 1235, 1237 (1980) (same). at 365 .

63. RESTATEMENT (SECOND) OF TORTS § 313(2) (1965); Prosser \& KeEton, supra note 18,

64. In Bovsun v. Sanperi, 61 N.Y.2d 219, 461 N.E.2d 843, 473 N.Y.S.2d 357 (1984), the court stated:

[The zone-of-danger rule] is premised on the traditional negligence concept that by unreasonably endangering the plaintiff's physical safety the defendant has breached a duty owed to him or her for which he or she should recover all damages sustained including those occasioned by witnessing the suffering of an immediate family member who is also injured by the defendant's conduct. Recognition of this right ... . involves a broadening of the duty concept but ... not the creation of a duty to a plaintiff to whom the defendant is not already recognized as owing a duty to avoid bodily harm.

Id. at 229,461 N.E.2d at 847,473 N.Y.S.2d at 361 . See also Prosser \& KEETON, supra note 18 , at 365.

65. See, e.g., Bovsun, 61 N.Y.2d at 228, 461 N.E.2d at 847,473 N.Y.S.2d at 361.

66. Id.

67. See Prosser \& KeEton, supra note 18, at 15-17. 
A ininority approach ${ }^{68}$ rejecting the zone-of-danger rule is followed in a growing number of jurisdictions. ${ }^{69}$ This approach was first formulated by the California Suprene Court in Dillon v. Legg. ${ }^{70}$ In Dillon, a mother who was outside the zone of danger was allowed to recover for shock and fear suffered as a result of seeing her child hit by a negligent driver. ${ }^{71}$ Rejecting the majority rule, the court reasoned that foreseeability should be the critical inquiry because duty is determined by the foreseeability of the risk of harm. ${ }^{72}$ The court held that if injury to a young child is foreseeable, then injury to the child's mother, who is likely to be present or in the vicimity, is also foreseeable. ${ }^{73}$ Although the court did not explicitly limit the class of potential plaintiffs to bystanders, ${ }^{74}$ most courts following the Dillon approach have imposed such a limitation. ${ }^{75}$

The Dillon approach is arbitrary to the extent that it requires the plaintiff's presence at the scene of injury. ${ }^{76}$ As one court noted, "[T] instant advice that one's child has been killed or injured, by telephone, word of moutl, or by whatever means, even if delayed, will have in most cases the same inpact. The sight of gore and exposed bones is not neces-

68. There is a third approach, known as the "impact rule," under which recovery for emotional distress is allowed only when the defendant makes physical contact with the plaintiff. This rule has been almost completely abandoned. See Comment, Dillon Revisited: Toward a Better Paradigm for Bystander Cases, 43 OH1о ST. L.J. 931, 933 (1982); Note, Garland v. Herrin: Surviving Parents' Remedies for a Child's Wrongful Death-The Pecuniary-Loss Rule and Reckless Infliction of Emotional Distress, 32 CLEV. ST. L. REV. 641, 660 (1983-1984).

69. E.g., Leong v. Takasaki, 55 Hawaii 398, 520 P.2d 758 (1974); Dziokonski v. Babineau, 375 Mass. 555, 380 N.E.2d 1295 (1978); Culbert v. Sampson's Supermarkets, Inc., 444 A.2d 433 (Me. 1982); Corso v. Merrill, 119 N.H. 647, 406 A.2d 300 (1979); Portee v. Jaffee, 84 N.J. 88, 417 A.2d 521 (1980); Ramirez v. Armstrong, 100 N.M. 538, 673 P.2d 822 (1983); Sinn v. Bnrd, 486 Pa. 146, 404 A.2d 672 (1979).

70. 68 Cal. 2d 728, 441 P.2d 912, 69 Cal. Rptr. 72 (1968).

71. Id. at $747,441 \mathrm{P} .2 \mathrm{~d}$ at $925,69 \mathrm{Cal}$. Rptr. at 85 .

72. Id. at 739, 441 P.2d at 919-20, 69 Cal. Rptr. at 79-80.

73. Id. at 741, 441 P.2d at 921,69 Cal. Rptr. at 81 .

74. The Dillon court stated that three inquiries should be made:

(1) Whether plaintiff was loeated near the scene of the accident as contrasted with one who was a distance away from it. (2) Whether the shock resulted from a direct emotional impact upon plaintiff from the sensory and contemporaneous observance of the accident, as contrasted with learning of the accident from others after its occurrence. (3) Whether plaintiff and the victim were closely related ....

Id. at 740-41, 441 P.2d at 920,69 Cal. Rptr. at 80 .

75. Indeed, the California Supreme Court later interpreted Dillon as requiring sensory and contemporaneous observation of the accident. See Justus v. Atchison, 19 Cal. 3d 564, 584, 565 P.2d 122, 135, 139 Cal. Rptr. 97, 110 (1977). See also Madison v. Deseret Livestock Co., 574 F.2d 1027, 1032 (10th Cir. 1978) (plaintiff who witnesses only the effects of the injuries cannot recover under Dillon approach); Shelton v. Russell Pipe \& Foundry Co., 570 S.W.2d 861, 866 (Tenn. 1978) (no cause of action stated where father did not witness the infliction of daughter's injuries); Schuck v. Christensen, 80 Wash. 2d 652, 657, 497 P.2d 937, 940 (1972) (no cause of action stated where mother did not observe sexual molestation of daughter).

76. See Pearson, Liability to Bystanders for Negligently Inflicted Emotional Harm-A Comment on the Nature of Arbitrary Rules, 34 U. FLA. L. REV. 477 (1982); Note, supra notc 68, at 662-64. 
sary to provide special impact on a parent."77 The public policy of limiting liability that underlies the zone-of-danger rule is responsible for this arbitrariness, though this policy plays a lesser role under the Dillon approach. ${ }^{78}$

The policy of limiting liability in the field of negligence accords with common sense notions of justice. Most people exceed speed limits on occasion, or are otherwise negligent in some way; sucli conduct, however, rarely results in serious injury. When it does, it is probable that the actor did not engage in exceedingly culpable conduct. Shielding the actor from burdensome liability by limiting the class of potential plaintiffs is therefore justified in such cases.

When the conduct in question is murder, lowever, competing public policy concerns enter the picture. Sheltering a murderer from liability affronts common sense notions of justice. In light of the degree of wrongfulness associated witli murder, public policy suggests that the murderer fully coinpensate all persons who are injured by his conduct. ${ }^{79}$

The fact that the murderer will be subject to criminal sanctions is not a justification for limiting liability. Under American civil law, the extent of liability is generally directly related to the degree of wrongfulness of the conduct in question. ${ }^{80}$ Moreover, criminal punisliment for inurder is imposed to redress harm suffered by society at large and not to redress harm suffered by the victim's family. ${ }^{81}$ This point is illustrated by the fact that families of murder victims are generally excluded from any participation in murder prosecutions. ${ }^{82}$

This is not to argue that there should be no linitation on liability. Certainly one can imagine cases in which it would be absurd to impose liability. For example, the Restateinent notes that the number of persons who suffer emotional distress at the news of the assassination of a President may be immense. ${ }^{83}$ Altliough there inay be a necessity to draw the

77. Tobin v. Grossman, 24 N.Y.2d 609, 617-18, 249 N.E.2d 419, 423-24, 301 N.Y.S.2d 554, 560-61 (1969).

78. See Pearson, supra note 76 , at $496-500$.

79. Cf. Lambert v. Brewster, 97 W. Va. 124, 138, 125 S.E. 244, 249 (1924) ("As for public policy, the strongest policy which appeals to us is that fundamental theory of the common law that for every wrong there should be a remedy."); Bauer, The Degree of Moral Faull as Affecting Defclldant's Liability, 81 U. PA. L. REV. 586, 596 (1933) ("Justice is made more or less roughly to fit the kind and degree of fault .... [T] [Te person in serious moral fault may well be held to a high degree of accountability.").

80. Prosser \& Keeton, supra note 18, at 37 (exposure to liability is "greatest . . . where the motive is a malevolent desire to do harm").

81. See id. at 7.

82. Murder is considered a crime against the state and prosecution is brought in the name of the state. W. LaFave \& A. Scott, Criminal Law 11 (1972).

83. See RESTATEMENT (SECOND) OF TORTS $\S 46$ comment $l$ (1965). 

resulted. ${ }^{90}$ The Court examined the basis for the traditional refusal to allow a civil recovery in such cases:

Legal historians have concluded that the sole substantial basis for the rule at common law is a feature of the early English law that did not survive into this century-the felony-merger doctrine.... According to this doctrine, the common law did not allow civil recovery for an act that constituted both a tort and a felony.... The doctrine found practical justification in the fact that the punishment for the felony was the death of the felon and the forfeiture of his property to the Crown; thus, after the crime had been pumished, nothing remained of the felon or his property on which to base a civil action..$^{91}$

Because felony punishment in this country does not include forfeiture of property, the historic justification for the rule no longer applies.92

It might nevertheless be argued that where wrongful death legislation has been enacted, it "occupies the field,"93 and thus recognizing an action for emotional distress where the legislature has not expressly provided for one would circumvent legislative intent. This argument is weak because a wrongful death action and an action for intentional infliction of emotional distress differ in an essential respect. The wrongful death action has traditionally been characterized as derivative, because the plaintiff recovers for an injury sustained by a third party (the deceased person). ${ }^{94}$ An action for emotional distress, on the other hand, is direct in nature; the mental distress for which recovery is sought is an injury personal to the plaintiff.

Several courts have expressly recognized this distinction. In $D e$ Cicco v. Trinidad Area Health Association, ${ }^{95}$ the court noted that a wrongful death statute is derivative while "[o]utrageous conduct . . . is a personal tort in which the misconduct of the tortfeasor caused direct injury to the person seeking recovery. . . . [R]ecovery for grief, and damages designed to punish are precluded in a wrongful death claim but may be the most significant factor in an action for outrageous conduct." 96

90. Id. at 381 .

91. Id. at 382.

92. Id. at 384-86. The Court concluded that the sole justification for the rule was that it had "the blessing of age." Id. at 386.

93. See, e.g., Liff v. Schildkrout, 49 N.Y.2d 622, 632, 404 N.E.2d 1288, 1291, 427 N.Y.S.2d 746,749 (1980) ("[L]egislative enactments have pre-empted this area . . ..").

94. See infra notes $95-98$ and accompanying text.

95. 40 Colo. App. 63, 573 P.2d 559 (1978).

96. Id. at 66,573 P.2d at 562. See also Knierim v. Izzo, 22 Ill. 2d 73, 81, 87, 174 N.E.2d 157, 162,165 (1961) (allowing plaintiff to bring actions for both wrongful death and emotional distress); Grimsby v. Samson, 85 Wash. 2d 52, 54, 59-60, 530 P.2d 291, 292, 295-96 (1975) (allowing plaintiff to bring action for intentional infliction of emotional distress though wrongful death claim was pending); cf. Limino v. Milford Key, Inc., 385 Mass. 323, 334, 431 N.E.2d 920, 927 (1982) ("[E]motional distress is a wrong to the plaintiff distinct from that done to [the decedent] and the statutory beneficiaries of the decedent ...."). 
And in Barnes v. Double Seal Glass Co.,97 the court distinguished the plaintiffs' claim from derivative claims brought under the wrongful death statute, characterizing the plaintiffs' claim as a 'claim for intentional infliction of emotional distress ... made on their own behalf, for their own injuries, for a tort directed at them rather than at their son."98

\section{Conclusion}

It is a harsh irony that perhaps the most outrageous of all conductmurder-is rarely actionable under the tort of outrage. The main obstacle to bringing such an action is the requirement that the plaimtiff be present at the scene of the murder. Although the presence requirement may be sound in other contexts, such as where the defendant intentionally inflicts injuries other than death or where he causes the victim's death negligently, it is unsound where the defendant commits murder. In such a case, the defendant recklessly and perhaps intentionally mflicts emotional distress on the victim's immediate family. Concerns about the genuineness of the suffering experienced by family members are misplaced. Furthermore, in light of the degree of wrongfulness associated with murder, common sense notions of justice dictate that a murderer should not be shielded from liability for distress suffered by family members. Although there may be a practical necessity to limit hability by drawing a line somewhere, the hine sliould not be drawn without a reasoned consideration of competing public policy concerns. There is no basis in either reason or policy to deny recovery to the immediate members of a murder victim's family merely because they were not present at the scene of the murder.

John W. McNamara

97. 129 Mich. App. 66, 341 N.W.2d 812 (1984).

98. Id. at 76,341 N.W.2d at 817 . 
